\title{
Prebendalism and Rural Poverty in Cross River State, Nigeria
}

\author{
Felix Onen Eteng ${ }^{1}$, Ikechukwu Jonathan Opara ${ }^{1} \&$ Hilary Adie ${ }^{1}$ \\ ${ }^{1}$ Department of Public Administration, University of Calabar, Calabar, Nigeria \\ Correspondence: Ikechukwu Jonathan Opara, Department of Public Administration, University of Calabar, Calabar, \\ Nigeria. E-mail: oparajonathan45@yahoo.com
}

Received: October 2, 2021

doi:10.5539/jsd.v14n6p87
Accepted: November 9, $2021 \quad$ Online Published: November 12, 2021

URL: https://doi.org/10.5539/jsd.v14n6p87

\begin{abstract}
Prebendalism and rural poverty are two main variables whose problems have negatively impacted on the developmental process of the state. This condition at the grassroots is commonly observed in the area of low income, poor shelter, poor health facilities, and in other socioeconomic wellbeing of the people. In this study, the main objective is to investigate the effect of prebendalism on rural poverty in cross river state. A quantitative research method was utilized. The findings of this study shows that prebendalism and rural poverty as the bane of development in the state are difficult to be eradicated. The implication is that unless prebendalism is eradicated, the wellbeing of the people at the grassroots will be a mirage. Therefore, this study attempts to provide policy directive along the line of the need for government to review its implementation of poverty programmes at the grassroots by eradicating or minimizing prebendalism.
\end{abstract}

Keywords: prebendalism, rural poverty, Cross River State

\section{Introduction}

Cross River State which was formerly known as South Eastern State is located in the old "oil river territory" which is now called Niger Delta region of modern Nigeria. The state is geographically found in the South South geopolitical zone of Nigeria. As at 2006, the state population was 2,892,98.8 (National Population Commission, 2006). In the year 2016, using 2.8 percent Growth Rate, the total population was projected to be 3,866,269 (National Bureau of Statistics, 2017).

A large part of the state is rural with rich natural resources such as cocoa, rubber, limestone, banana, and forest reserve for wildlife and game reserve. The state has many ethnic groups with diverse cultural traditions and languages which hinders communication except through the use of English language as the official language. According to Agbor \& Eteng (2018) "the various ethnic groups have produced a 'Tower of Babel' which is highly demonstrated by nearly kilometer to kilometer differences in language".

Since 1976 when the Federal Military Government of General Murtala Muhammed renamed the state as Cross River State with the appointment of a military governor for the state, there has been wide spread practice of prebendalism which has serious consequences on the socioeconomic wellbeing of the rural dwellers. The rural areas have been neglected in various areas such as access roads, supply of electricity, potable water supply, good shelter, amenities and facilities like healthcare centers, rural banking system as well as rural industrialization of the area. These lamentable socioeconomic conditions at the grassroots have been attributed to the practice of prebandalism as a political value of the ruling elites in decision making process. Eteng \& Omenka (2016) opined that "conditions at the grassroots are depressing and people become daily frustrated due to inequality in areas like contract award, employment opportunities, skill acquisition, and capacity enhancement."

Prebendalism in the state has given rise to "primordial identity" (Joseph 1999) that have resulted in segregation in employment into public offices. Consequently, young school leavers from the villages roam the urban cities for employment and some of whom with good certificates but nothing to show for it except they have the right political connection. Political connection for appointment into the state bureaucracy or political offices is only attained through the support of a government candidate during electioneering campaign or having an influential tribal kinsmen in government. Eteng \& Anam (2019) maintained that "hardship and sorrows confront the poor in the society on daily basis. Most vulnerable are the aged, those living with HIV \& AIDs and orphans".

Based on the negative impact of prebendalism on the general wellbeing of the rural dwellers in the state, this study will be aimed at seeking for a way forward to this problem in order to ameliorate the deplorable poor conditions 
of the masses at the grassroots. The ability to do this correctly will form the main focus of the study.

\subsection{Conceptual Clarification}

The two main concepts that need to be clarified for the purpose of facilitating understanding in this study are: prebendalism and rural poverty. These two concepts forms the basis of our discussion.

Prebendalism: In ordinary term, prebendalism will refer to the practice of "god fatherism." This concept which negates the developmental process of the society promotes corrupt enrichment, mismanagement, favouritism, nepotism and segregation in employment or appointment into public offices or bureaucracy. Eteng \& Adie (2016) defined prebendalism as "a term which seeks to describe the determined activities of the political process in the state or take advantage of the public offices they occupy". On the other hand, Joseph (1999) opined that "because of the corrupt activities of the political leaders they become rich at the expense of the poor masses." Generally, prebendalism may be defined as a concept which is anti-human and antinational in nature and is perpetually hostile to the developmental process of the vast majority of the poor who daily yearn for opportunity to better their socioeconomic conditions in order to fulfil their aspirations and goals.

Rural poverty: Rural poverty is a deplorable socioeconomic condition in which the people at the grassroots cannot have the means to satisfy their basic needs such as good shelter, clothing, warmth, health, etc. Rural poverty is a miserable condition, which hinders the people at the grassroots to make progress or fulfil their desire as others who live in the urban areas. The condition of those who live in rural areas in Cross River State need to be imagined than experienced. Rural poverty is real and is observable in terms of low income earning, poor shelter or having no roof over them, lack of portable water, and insecurity. Terrorist operation, kidnapping (hostage taking) have made rural life dreadful. In short, rural poverty may be defined as a condition of deprivation in which the rural dwellers lack the ability to improve their social condition due to poor income, lack of basic amenities and access to modern technological and industrial needs of the society.

\subsection{Analysis of Prebendalism and Rural Poverty in Cross River State}

Rural poverty in Cross River State is real and is observable in the areas of low income earning, poor shelter, lack of social amenities like electricity, potable water, poor health facilities, lack of access roads and poor funding of rural schools and some of the buildings being in a state of disrepair. This miserable socioeconomic conditions of the rural areas have been tied to the negative effect of prebendalism which the ruling elites have adopted as a political practice to handle the general wellbeing of the people at the grassroots in order to corruptly enrich themselves through mismanagement and embezzlement.

The experience of the people at the grassroots in the state is not a pleasant one as the overall activities of the political elites have serious negative consequences on the people. One can observe the negative manifestation of prebendalism in the area of employment or appointment into the state bureaucracy or political offices. An individual who wants employment or appointment must have supported a government candidate during political party campaign in electioneering process or must have an influential person in government as Chief Executive or one who occupies a managerial position. This condition has hindered many rural young school leavers from getting employed in government due to lack of tribal kinsmen or friends to help them. Equally, this condition has made many communities to agitate for representation in government giving rise to "ethnic watchers" who gaze to see who will get appointed into the State Executive Council.

The poor in the rural areas have no portion in the award of contract. This is because the vast majority of the rural people are illiterate and cannot correlate cause and effect. This benefit is beyond them due to the conditions attached to it. Many of the people who benefit from the award of contracts are city dwellers who are educated and know the value of wealth and must have supported the party during elections. Richard Joseph (1999) made this point clearly in his analysis of what is going on in Nigeria of which the state is an integral unit:

A man who supports the party in office will be rewarded with contract for official projects, enabling him to pass on largesse to those further down the line who look to him for generosity (Joseph, 1999).

The huge lamentation and cry among rural farmers in the state is in the prebendal practice of distributing fertilizers to deserving local farmers. The political elites in the bid to favour those who supported them during political party election evolved a channel of getting to the grassroots through ward chiefs or traditional leaders who supported them. This channel of distributing social goods and benefits has negative effect on many rural farmers who are often denied the right to the use of fertilizer. In an interview, Eteng \& Adie (2016) expressed this huge cry and agony of the rural farmers as follows:

When fertilizer comes from the government, it is stored in the palace of the 
Ward Chief, and is then distributed only to party supporters, relatives or friends of the political leaders. Most of us blame our plight to the dominance of only one political party in the state so that if you are not rightly connected to the leaders, then you are out. This has been the practice for many years. (Eteng \& Adie, 2016).

The state rural electrification project which was embarked upon by the civilian government of Governor Lyel Imoke was seriously marred by prebendal forces. Most electricity poles that were supplied for use by government only ended in the hands of the local councilors who represented the local people at the grassroots. In most cases, these councilors merely covert the poles and use them on the roads leading to the residence of their friends, relatives or personal buildings. The result of this practice is that majority of the rural dwellers are being denied of the use of electricity and are still living in the dark without electricity supply. Consequently, many rural dwellers lack access to information that could have helped them to develop themselves.

At present, the state has a weak technological and industrial base due to prebendal location of certain industries in the urban areas rather than in the rural areas where the raw materials are found. The collapse of some cottage industries like the Dura form Industry, Calabar plywood, CAVENPLY Industry, etc. have been due to the siting of these industries in areas where the raw materials are virtually absent. The collapse of the only state own cement industry (Calabar cement Company Limited) due to its urban location as well as political insinuations led to a government wise decision to establish a new cement company known as Lafarge Africa Plc. in the village of Mfamosin where limestone is found.

Water supply in the rural areas is still a problem. Most communities and villages rely on streams, rivers, and ponds as major sources of water supply. The World Bank assisted water projects did not benefit the vast majority of the people due to prebendal practice of directing such water projects to communities or villages that have influential people in government. The result is that at periodic intervals, cholera outbreak in some of these communities have led to several deaths due to poor water supply. In some communities, rivers are used by people to defecate or throw refuge which is harmful to people who depend on the river as a major source of water supply.

In most communities or villages, there are no access roads. Forest foot paths are major access roads that the rural dwellers utilize as a means to get to other villages. The villagers are often attacked by snakes and other wild animals which make movement difficult mostly at night. The State Rural Road Programme that was intended to cover all rural areas in the state was a colossal failure because of prebendalism. In order to fulfil the promise made to the people during electioneering campaign, the political leaders prefer to create access roads only in communities that supported them. The result is that other communities that failed to support them during elections were denied access roads as punishment for not supporting them, and also as a bait for support in future electioneering campaigns.

Many rural dwellers live in "scattered homestead" without any property of their own. In most cases, they lack the roof to cover themselves and their families with large number of children. The state government housing programme did not cover the rural areas. The frustration of having no roof over their families have made some to resort to drunkenness as a means of escape from the thought and reality of the difficulties facing them.

Lack of access to qualitative education has serious effect on rural poverty. Majority of the villages especially those living in the Creek and riverine areas of the state lack access to qualitative education. Most schools are poorly funded without adequate teachers and some schools buildings are in a state of dilapidating and the government is doing nothing about it. Many primary school children trek long distances to school without shoes and good clothes, and sometimes without breakfast. Although the government in collaboration with the Federal Government introduced a school meal programme which was solely to feed children and reduce hunger in school, yet this programme was hijacked by the wives, relatives and supporters of the political ruling class who mismanaged, and poorly fed the children in school. For instance, the quality of food was poorly prepared and about three to five children were made to share an egg in school. This miserable situation led to the collapse of the programme without any solution to the already impoverished condition at the grassroots.

\section{Literature Review}

In this study, attempt to review some previous academic studies conducted by scholars in prebendalism and rural poverty will be carried out. This is intended to highlight the ideas of other scholars in order to fill the gap in literature between this study and other scholars in the subject matter of our enquiry. This review is also intended to add value to the existing knowledge on prebendalism and rural poverty. In line with this, the study will adopt a conceptual review on prebendalism and rural poverty. 
Prebendalism: Prebendalism is a sociopolitical practice among political elites with negative effect on the wellbeing of the people. In attempt to examine the role of this concept in Nigeria, Eteng \& Omenka (2016) maintained that:

The term prebendalism seeks to explain what political leaders do in order to corruptly enrich themselves and transfer the wealth in the form of largess to family members, friends or supporters. It is the rapacious practices that sustains the ruling elites, and make them hold on to power as a do or die affair.

Joseph (1999) described it as:

A variety of political behavior in which an individual enjoys the backing of a "big" person (often described as a master or "Oga") in order to benefit from the government in the area of contract award, employment, appointment into the Board of a parastatal, award of scholarship as well as success in business.

In assessing the role of prebendalism in the development of Cross River State, Nigeria, Eteng \& Anam (2020) opined that the term is often used to refer to

The prevalent practice among political leaders that negates the socioeconomic fortunes of a nation state due to corruption, favouritism or "god fatherism" and is carried out mainly for the interest of the individual, tribal kinsmen, family or party supporters for their past support during electioneering activities.

They argued that the term is a common practice in many nations of the world especially in Africa, Latin America, or Asia.

Bartholomew, I. U. (2015) maintained that prebendalism is a political system where elected officials, and government workers feel they have a right to share government revenue and use them for the benefit of their supporters, co-religionists and members of their ethnic groups.

Obo \& Adejumo (2014) described prebendalism as:

Patterns of political behaviour and governance processes characterized by massive corruption in which state offices and political power are acquired and deployed mainly for private accumulation of wealth (Obo \& Adejumo, 2014).

Commenting on the concept of prebendalism, Dommen observed that it is:

A system of shared identity and social solidarity expressing itself through a circuit which concentrates and redistributes income, and exclusive is a result of the absence of social bond between the insiders and the outsiders (Dommen 1997).

Segun Ayobolu (2011) cited in Joseph (2013) explained the conditions that exist in prebendalism in Nigeria as follows:

Occupants of public office at all levels in the Second Republic felt that their positions entitled them to unbridled access to public resources with which they not only satisfy their own material needs, but also serviced the needs or wants to subaltern clients (Joseph 2013, file///.D:/Prebendalism and Dysfunctionality in Nigeria Africaplies.htm:1 of 15).

According to Ogbuene, R. (2008) prebendalism as it is obtained in Nigeria can be perceived from two major perspectives. One, is a situation where political offices are regarded as prebends that can be appropriated by their holders and actually used as benefit for themselves, relatives or kinsmen. Two, as a form of political clientelism in which people ascend to political offices through the active support of power brokers (political god fathers) who in turn benefit from the public office holder. However, from these two perspectives, prebendalism could be taken to mean the use of political offices for direct selfish and personal gains.

In evaluating these various positions of scholars on prebendalism, it is not difficult to identify the nefarious activities of many political elites in many countries particularly in Africa. This condition which easily spread like a "bush fire" has in the past led to military intervention in Nigeria, Ghana and some parts of Asia and Latin America. It is what political leaders practice in order to maintain their power position and sustain their continuous existence in public offices.

\subsection{Rural Poverty}

Rural poverty is a condition whereby the masses at the grassroots lack the means to sustain themselves. Odumosu 
(1999), vividly described the conditions of the poor at the grassroots as follows:

Starvation and death stare at his face as in medieval times. Indeed, time have not changed since the Dark ages. And as though these afflictions were not enough, it is he - and this is the greatest agony of all - who gives birth to the large number of children thus spreading and multiplying misery to a dark universe of destitution. When death come to him finally, he seems to be happier than those he has left behind him (Odumosu, 1999)

Similarly, in his theoretical article, Odumosu (1999) highlighted what the poor suffers particularly at the grassroots. In his opinion, the poor at the grassroots:

Suffers from apathy and ignominy; from birth to death, remains a destitute, usually dies an infant, but if he does survive, death and want haunt him to his end. Flood, famine, drought and other natural disasters continually plague him ... rarely has roof over his head (Odumoso 1999).

Food and Agriculture Organization (2021), descried the rural poor as the most vulnerable set of individuals that lack social security network. They are household agriculturalists, sustenance manufacturers, landless agrarian labourers and heavily reliant on the forest. This definition is a comprehensive description of rural poverty in that it touches on the main concern of the rural people which is lack of social protection and inability to lay claim on any tangible productive asset. http://www.fao.org/reduce-rrual-poverty.

Ering (2004) defined rural poverty as "a condition of general lack which includes food, health, accommodation, income, water, education, etc."

Giving Compass (2021) described rural poverty as a condition at the grassroots in which people find it difficult to gain access to market, schools, social amenities, job chances and health insurance. Accordingly, there is nothing to write home about the living conditions of the poor because they live in squalor environments, poorly constructed houses and road network. The level of hardship suffered by the rural people is second to none. The women and children are mostly engulfed by the shackles of rural poverty. https://givingcompass.org

Jagran Prakashan (2021) described rural poverty as the type of hardship suffered by most individuals that live in the countryside. Thus, the rural poor are mainly jobless, less educated and lacked the opportunity to be wellinformed. They lack access to social amenities and are mostly subsistent farmers. The roads that lead to the dwellings of the poor are usually bad and this account for the inability of the poor to convey their farm produce to the city where they would sell and make profit. The submission of this argument is that the poor is made incapacitated by environmental factors. https://www.jagranjosh.com

Todaro \& Smith (2015) observed that most of the rural dwellers lack what it takes to provide or cater for their basic needs. They are mainly involved in agricultural related occupations. However, greater number of the rural poor are women, children and the aged.

In assessing these ideas on rural poverty, it can be observed that rural poverty consist of lack of social security network, lack of good environment, lack of good houses, lack of comfort, lack of access to education and roads, healthcare and poor income. Finally, the rural areas are lonely and a large number of the poor at the grassroots are children, women and the aged.

\section{Methodology of Study}

In this study, data will be obtained from both the primary and secondary sources of data collection. The primary source of data collection include: interviews, observation, and group discussions while the secondary source is made up of periodic journals, internet services, documentary studies, bulletin, textbooks and information from family records.

A quantitative research method will be utilized in this study. The study adopted the survey research method to enable it carryout community surveys as well as household surveys as follows: household location and size, health status, occupation, employment status, education, productivity and outpust, as well as nutritional value of a household. On the other hand, for the community survey, data were obtained based on the facilities and services available in the existing communities.

In order to facilitate process and carryout a study in which communities and households will have equal chances of being selected, a stratified sampling method was utilized to select nine (9) local government areas out of the eighteen (18) local government areas that constitute the state. Since the state is made up of three (3) geopolitical zones known as Senatorial districts such as Northern, Central and Southern Senatorial districts, the study selected 
three (3) local government areas from each senatorial district. From the Northern senatorial district the following local governments were selected: Bekwarra, Yala and Obanlikwu. In the Central Senatorial district, Yakurr, Obubra and Boki were selected. In the Southern Senatorial district, Biase, Akamkpa and Akpabuyo local government areas were selected. The selection of these nine (9) local government areas in the three senatorial districts was done thorough a stratified sampling method in which all the local government areas in each senatorial district were listed in pieces of paper that was rolled into small paper balls put in a vessel (container) and mixed thoroughly from where only three where chosen as representative of the entire population. This method was also used in the selection of communities in the local government areas selected.

However, based on the local government areas selected, and depending on the total population of the state which in 2016 was projected to 3,866,269 (national Bureau of Statistics, 2017), one thousand, three hundred and fifty (1350) respondents were selected through the stratified sampling method. Out of this, only one hundred and fifty (150) respondents were chosen from each local government area. This selection was purposive. This was intended to get the actual persons (respondents) who have knowledge of the subject matter of our enquiry in order to provide the required information for the study.

The selected respondents include: the unemployed, farmers, petty traders, artisans, teachers and politicians who inhabit the rural areas. As a result of the sampling size mentioned above, the study adopted a stratified sampling technique to classify the sampling size into various groups using the following distribution quota: unemployed 600 , farmers 400 , petty traders 150 , artisans 100 , teachers 80 , politicians 20 . A research questionnaire was used for the study. Out of a total of one thousand, three hundred and fifty questionnaires that were distributed, only fifty questionnaires were not returned giving the attrition rate of 3.7 percent.

\section{Findings}

Table 1. Respondents' views on the effect of prebendalim on rural poverty

\begin{tabular}{llrrrr}
\hline & & & & \multicolumn{2}{c}{ Cumulative } \\
& & Frequency & Percent & Valid Percent & \multicolumn{1}{c}{ Percent } \\
\hline Valid & Unemployed & 600 & 44.4 & 44.4 & 44.4 \\
& Farmers & 400 & 29.6 & 29.6 & 74.1 \\
& Petty Traders & 150 & 11.1 & 11.1 & 85.2 \\
& Artisans & 100 & 7.4 & 7.4 & 92.6 \\
& Teachers & 80 & 5.9 & 5.9 & 98.5 \\
& Politicians & 20 & 1.5 & 1.5 & 100.0 \\
& Total & 1350 & 100.0 & 100.0 & \\
\hline
\end{tabular}

Source: field work 2021

From table 1 above, it is obvious that all the categories of our respondents affirmed that prebendalism is responsible for increasing rate of rural poverty in rural Cross River State.

\begin{tabular}{|l|l|r|r|}
\hline \multicolumn{2}{|c|}{} & Prebendalism & Rural Poverty \\
\hline Prebendalism & Pearson Correlation & 1 & $1.000^{* *}$ \\
\cline { 2 - 4 } & Sig. (1-tailed) & & .000 \\
\cline { 2 - 4 } & $\mathrm{N}$ & 6 & 6 \\
\hline \multirow{2}{*}{ Rural Poverty } & Pearson Correlation & $1.000^{* *}$ & 1 \\
\cline { 2 - 4 } & Sig. (1-tailed) & .000 & \\
\cline { 2 - 4 } & $\mathrm{N}$ & 6 & 6 \\
\hline \multirow{2}{*}{$* *$ Correlation is significant at the 0.01 level (1-tailed). } \\
\hline
\end{tabular}

Figure 1. Correlation analysis result for prebendalism and rural poverty

Source: field work 2021 
From figure 1 above, it can be observed that the correlation coefficient between prebendalism and rural poverty is 1.000 and the $P$ value is 0.000 , which shows that there is a positive relationship between prebendalism and rural poverty. The implication of the correlation analysis is that prebendalism is responsible for rural poverty in Cross River State. Also, rural poverty in Cross River State can be reduced if prebendalism is curtailed drastically.

\subsection{Government Policy Response}

The Cross River State Government in response to these incidences of prebendalism and rural poverty introduced some laws and anti-poverty programmes to cushion the harsh effect of prebendalism and rural poverty at the grassroots. Some of these laws and policies are in collaboration with the existing policies of the federal government. The following are a few examples:

- Economic Financial Crimes Commission (EFCC) Act

- Primary Healthcare Programme (PHC)

- Better Life for rural Women

- Nomadic Education Programme

- Establishment of rural baking

- Family Economic advancement Programme (FEAP)

- Guinea Worm eradication programme

- Integrated Agricultural and Rural Development Project

- Establishment of Community Banks

- National Directorate of Employment (NDE)

- Back to Land programme

- Independent Corrupt practices Commission (ICPC) Act

- Green Revolution Programme.

\subsection{Challenges of Eradicating Prebendalism and Rural Poverty in Cross River State}

It has been observed that despite the government policy response to prebendalism and rural poverty, this problem is unabated and continues to exist in alarming rate that is difficult to eradicate. The continuous existence of prebendalism and rural poverty has been due to the following reasons.

Bad governance: The political elites in the state are aware of the existence of prebendalism and rural poverty in Cross River State but failed to tackle the problem because of the craze for wealth. They know the value of wealth and many of them have in the past occupied wealthy positions during the military regime of General Babangida. Thus as soon as they occupy new positions in government, they become crazy to get rich quick by conniving with the local Chiefs to defraud the poor at the grassroots through embezzlement, mismanagement, misappropriation and other corrupt practices. This practice persist till today and is unchecked because of bad governance.

Leadership failure: Leadership failure in the state has given rise to segregation in terms of employment in the state bureaucracy or who benefit from the government. The political and administrative elites prefer their tribal kinsmen, wives, or relatives to benefit from the government. This practice of the leaders in the choice of who benefit from the government had led to the collapse of the state poverty eradication programme that was intended to cushion the sufferings of the people at the grassroots and upon whom the poverty programme was targeted in order to alleviate their problems.

Weak technological and industrial base: The state has weak technological and industrial base. Part of the reason for this condition is the problem associated with implementing the National Policy of Import Substitution Industrialization Development model that places emphasis on wholesale importation without the enabling environment to sustain it. This problem is mostly felt in the importation of spare parts and the assembling of these spare parts under the umbrella of a "manufacturing plate form" (Bassey \& Ndiyo, 2017), cited in (Eteng \& Anam, 2019). Secondly, Research and Development ( $\&$ D) which could serve as a catalyst to industrialization is lacking in the state instead the state government annually spends large sums of money on sports and carnival activities. This poor condition in the state has negative effect in terms of establishing strong industrial base to provide employment opportunities for the poor in order to reduce dependency on government and the prebendal lords of the state. 


\subsection{Way Forward}

The findings of this study shows that prebendalism and rural poverty are difficult to be eradicated due to bad governance and leadership failure. Therefore, it is necessary to provide a way forward as solution to the problem. This will help to minimize if not eradicate the problem.

Review of poverty programmes implementation: The implementation of the various poverty programmes in the state should be reviewed. This will involve proper targeting of the poor in order to identify those who need to benefit from the poverty programmes. Proper targeting will minimize the error of sidelining the poor at the grassroots and enhance adequate participation in the empowerment programmes of skill acquisition and capacity enhancement schemes. This also requires a good evaluation and monitoring process that is capable of promoting accountability at all levels of government in order to eradicate if not minimize prebendalism.

Strengthening the existing laws: As part of the government policy response to avert prebendalism and reduce poverty, two main Acts were enacted by the Federal Legislature and are domiciled in all states of the federation. These are the Economic Financial Crimes Commission (EFCC) Act and the Independent Corrupt Practices Commission (ICPC) Act. These laws are intended to punish offenders. At present, the government is only using it as a weapon against political opponents to silent opposition. However, these laws need to be strengthened and be applied to all persons without regard to status or political affiliation. This will promote justice, equity and fair play and deter offenders from further committing the offence.

Adequate budgetary allocation: There should be adequate budgetary allocations for all the government agencies that are responsible for combating prebendalism and rural poverty in the state. Unfortunately, the situation in Cross River State is that gross inadequate resources are often available to wage war against prebendalism and rural poverty. Part of the reason for these inadequate resources in the state is the slim nature of the revenue that accrue to the state from the federation account based on a formula legally agreed upon by all the units of the federation. According to Eteng \& Agbor (2018)"the state government receives 26.72 percent". This is far below what other states of the federation receive from the statutory allocation of the federation account. Other sources of the state revenue include investments and taxes which is still grossly inadequate. The implementation of government policies at all levels requires a good purse. In the opinion of Eteng \& Agbor (2018) "development feats are largely tied to the amount of revenue available to the government." Therefore, there is need to increase the revenue base of the state. This will provide the state with enough resources to fight against prebendalism and rural poverty.

Expansion of the state industrial base: This will help to absorb the unemployed youths who roam the streets for gainful employment in the state bureaucracy. It will also expand the revenue base of the state. However, to facilitate process, there is need to provide facilities and enabling environment for industrial development. Research and Development (R\&D) as drivers or catalyst for industrialization should be encouraged. This will in turn provide the state with a buoyant economy that can help to combat prebendalism and rural poverty.

Village renewal programme: At present, the state is mainly focused on urban renewal programmes to the neglect of the rural areas. There should be a village renewal programme which should be targeted towards making the rural areas attractive through the provision of social services and amenities that can boast rural development. Eteng \& Anam (2016) opined that:

The concept of village renewal proposes that there are current practices that need to be incorporated into the village planning and development. This is distinct from the periodic traditional practices of decorating village squares, play grounds, shrines and palaces during annual festivals and ceremonies to attract visitors and tourists.

Therefore, a successful village renewal programme will involve restructuring the villages so as to attain "an ultramodern outlook" (Eteng \& Anam, 2016) as well as the preservation of the natural valleys, mountains, forest, population and economy, etc.

Rural development: This will involve the intervention of the state in order to eradicate all the hindrances that may pose as obstacles to rural development. This requires creating access roads, deforestation, rural electrification, rural industrialization, creating of captive markets to boast agriculture and improve the income of the rural settlers through buying and selling. Others include providing skill acquisition programmes for the unemployed, and giving incentives like loan or grant to deserving farmers through rural or community banks.

Role of Non-Governmental Organisations (NGOs) \& Civil Societies: As private organizations that often indicate interest towards alleviating the sufferings and pains of the people, they should provide infrastructural development at the grassroots. They can also provide training and technical assistance to villages or communities for 
development. Finally, they should provide the linkages required between the grassroots and the government in terms of communication.

\section{Conclusion}

This study is focused on prebendalism and rural poverty in Cross River State, Nigeria. In order to ease understanding, the study carried out a conceptual clarification of the variables of prebendalism and rural poverty. A brief literature review was made to examine scholars' perception of the two variables under consideration. Data were obtained from primary and secondary sources. A survey research method was also utilized to carryout community and household surveys.

The study tried to examine the state government policy response to prebendalism and rural poverty. At the end, it was observed that despite the policy response of the government, prebendalism and rural poverty are difficult to be eradicated because of bad governance and leadership failure, etc.

Based on these findings, the study recommends as follows:

- That the government implementation policy on poverty programmes in the state should be reviewed with the aim to minimize if not eradicate prebendalism.

- That the existing laws in the state should be strengthened and more powers be given to the various agencies handling economic and financial crimes in the state as well as punish offenders without regard to party affiliation or status.

- That adequate budgetary allocations should annually be made to provide enough funds to the agencies whose responsibilities are to fight against embezzlement, mismanagement and corrupt enrichment in the state.

- That the state industrial base should be expanded. This will provide the government with a buoyant economy to handle the poverty situation in the state. To this end, the citizens should vote transparent persons into power during electioneering period in order to promote good leadership and accountability.

- Finally, the state should embark on village renewal programmes, pursue rural development policies as well as partner effectively with the Non-Governmental Organizations (NGOs) and Civil Societies in order to better the wellbeing of the people at the grassroots.

\section{References}

2006 National Population Commission.

2017 National Bureau of Statistics (NBS).

Bartholomew, I. U. (2015). Prebendalism as the albatross to Democratic practice and National Development in Nigeria: A Critical Discourse. Journal of Policy and Development Studies, 9(4). https://doi.org/10.12816/0016772

Demographic Statistics Bulletin.

Dommen, E. (1997). Paradigms of governance and exclusion. Journal of Modern African Studies, 33(3). https://doi.org/10.1017/S0022278X97002528

Ering, S. O. (2004). A monograph on poverty and social work. Calabar: DC Avizona's Publishers.

Eteng, F. O., \& Adie, H. I. (2016). Prebendal Politics, Poverty Pervasiveness and Eradication in Cross River State, Nigeria. International Journal of Education and research, 4(1).

Eteng, F. O., \& Agbor, U. I. (2018). The Challenges of internal revenue generation and inclusive development of local government areas in Cross River State, Nigeria. International Journal of Public Administration and Management Research (IJPAMR), 4(4).

Eteng, F. O., \& Anam, B. E. (2016). Village renewal and development in Cross River State, Nigeria. International Journal of Humanities and Social Science Research, 2(7).

Eteng, F. O., \& Anam, B. E. (2019). The Challenges of Ending Poverty in Cross River State, Nigeria. International Journal of Business and Management Invention (IJBMI), 8(03), Series V.

Eteng, F. O., \& Anam, B. E. (2020). Prebendal Politics and Development in Cross River State, Nigeria. Journal of Humanities and Social Science. (JOSR-JHSS), 25(2), Series 11.

Eteng, F. O., \& Omenka, J. I. (2016). Ethnic Plurality, Prebendalism and Poverty reduction in Nigeria. International Journal of Research in Social Sciences, 6(8). 
Eteng, F. O., \& Omenka, J. I. (2016). Prebendalism and National Poverty eradication Programme in Rural Cross River State, Nigeria. International Journal of Research in Social Sciences, 6(4).

Food and Agriculture Organization. (2021). Reduce Rural Poverty. Retrieved from http://www.fao.org/reducerural-poverty

Jargran Parksahan. (2021). What is poverty and its types. Retrieved from http://www.jagranosh.com

Joseph, R. (1999). Democracy and Prebendal Politics in Nigeria: The Rise and Fall of the Second Republic. Ibadan: Spectrum Books Ltd.

Joseph, R. (2013). Prebendalism and dysfunctionality in Nigeria. Journal of Democracy, 23(1). Retrieved from https://africaplus.wordpress.com/.../prebendalism-and-dysfucntiionality

Kharas. (2021). Differences between Rural and Urban Poverty. Giving Compass LLC. Retrieved from http://www.givingcompass.org

Nnoli, O. (1980). Ethnic Politics in Nigeria. Enugu: Fourth Dimension Publishers.

Obo, U. B., \& Adejumo, T. O. (2014). Uruguay's Jose Mujica and Nigerian rulers: Selfless and exemplary leadership versus prebendal and runinous rullership. Review of History and Political Science, 2(1).

Odumoso, O. (1999). Social effects of poverty on the non-poor in Nigeria cited in Felix Onen Eteng (2015), "Prebendal politics and the administration of National Poverty Eradication Progrmame (NAPEP) in rural Cross River State, Nigeria" (An Unpublished Ph.D Dissertation, Department of Political Science, University of Calabar, Nigeria).

Ogbuene, A. (2012). Prebendalism: A Precursor to security Challenges in Nigeria. Journal of Policy and development Studies, 6(1).

Todaro, M. P., \& Smith, S. C. (2015). Economic Development $12^{\text {th }}$ edition: Pearson Education Limited; Edinburgh Gate, Harlow: United Kingdom.

\section{Copyrights}

Copyright for this article is retained by the author(s), with first publication rights granted to the journal.

This is an open-access article distributed under the terms and conditions of the Creative Commons Attribution license (http://creativecommons.org/licenses/by/4.0/). 